\title{
Changes in Intergenerational Mobility in Britain
}

\author{
Jo Blanden, Alissa Goodman, \\ Paul Gregg and Stephen Machin
}

June 2002 
Published by

Centre for the Economics of Education

London School of Economics and Political Science

Houghton Street

London WC2A $2 \mathrm{AE}$

(C) J. Blanden, A. Goodman, P. Gregg and S. Machin, submitted June 2002

ISBN 0753015307

Individual copy price: $£ 5$

The Centre for the Economics of Education is an independent research centre funded by the Department for Education and Skills. The views expressed in this work are those of the authors and do not necessarily reflect the views of the DfES. All errors and omissions remain the authors'. 


\section{Executive Summary}

This paper flatly contradicts the common view that anyone can make it in modern Britain. Indeed, rather then weakening, the link between an individual's earnings and those of his or her parents has strengthened. An important part of the explanation is that the expansion of higher education has benefited people from rich families much more than those from poor families.

The extent of intergenerational mobility is frequently seen as a measure of the degree of equality of opportunity in society and considerable research has been devoted to obtaining an accurate estimate of it for a number of countries. However little is known about how these connections have altered through time. Sharp increases in educational attainment and rises in earnings (and living standards in general) in more recent generations mean that many observers seem to think that we mw live in a more mobile, meritocratic society than in the past. Contrary to this, this research seems to show that where you come from matters more now than in the past. It appears that the extent of intergenerational mobility has actually fallen.

The research uses unique data that follow two cohorts of children (one born in 1958, one born in 1970) through childhood and into adulthood. The latest data, collected in 2000, make it possible, for the first time, for researchers to get a good measure of the adult earnings of the second cohort. The key findings are:

- The connection between earnings and parental income has strengthened for the more recent cohort. Estimates of the relationship between childhood family income and son's adult earnings show that for the 1958 cohort, a son from a family with twice as much income as a second family will earn about 12 percent more in his early thirties than a son from the second family. In the 1970 cohort, the same figure is 25 percent. Therefore, the degree of intergenerational transmission has risen by 13 percentage points. Results for daughters are very similar.

- Part of the fall in mobility across generations is due to the fact that the expansion of the higher education system has benefited people from rich families much more than those from poor families. This is particularly the case for daughters. 
The results show that differences in educational attainment across family background have led to a decline in equality of opportunity. This is despite the large expansion in postcompulsory schooling that occurred between the two cohorts. This may be unexpected to some observers, who see great gains in education and earnings from one generation to another and leave the story there.

But these gains have been unequally distributed across society. The majority of beneficiaries have been children from families who were already doing well. If, as seems to have happened, able children from lower income families are excluded from the expansion of education, this will lower national productivity and income in the long run.

The implication for government policy is clear. If equality of opportunity is a serious goal of government, it can be facilitated in a way that can enhance economic welfare via policies directed at high ability children whose parents are doing less well. 


\title{
Changes in Intergenerational Mobility in Britain
}

\author{
Jo Blanden, Alissa Goodman, \\ Paul Gregg and Stephen Machin
}

1. Introduction 1

2. Related Work and Modelling Questions 2

3. The Data 7

4. Estimates of Changes in Intergenerational Mobility 8

$\begin{array}{lll}\text { 5. Conclusions } & 15\end{array}$

$\begin{array}{ll}\text { Tables } & 17\end{array}$

$\begin{array}{ll}\text { References } & 24\end{array}$

The Centre for the Economics of Education is an independent research centre funded by the Department for Education and Skills. The views expressed in this work are those of the authors and do not necessarily reflect the views of the DfES. All errors and omissions remain the authors. 


\section{Acknowledgements}

We would like to thank Miles Corak and other participants in a workshop on Intergenerational Mobility held at Statistics Canada in February 2001, the follow up Berlin meeting of June 2001, the conference for the opening of the LSE research laboratory and the Research Council of Norway's Labour Market and Wage Formation conference in Oslo for a number of helpful comments.

Jo Blanden is at the Centre for Economic Performance, LSE and the Department of Economics, University College London. Alissa Goodman is at the Institute for Fiscal Studies. Paul Gregg is at the Centre for Economic Performance, LSE and the Department of Economics, University of Bristol. Stephen Machin is at the Centre for Economic Performance, LSE and the Department of Economics, UCL.

This paper is an updated version of CEP discussion paper No 517 published in December 2001. 


\section{Introduction}

The extent to which an individual's economic or social success is shaped by the economic or social position of their parents is a contentious and hotly debated issue, both within academic circles and in a wider policy context. There is a large body of academic work, carried out predominantly by sociologists, on social mobility ${ }^{1}$ where social class of individuals is related to parental social class, and a smaller body of work which considers mobility in terms of economic status (usually measured by labour market earnings of children and parents). ${ }^{2}$ Time and again the issue of intergenerational inequalities crops up in the political arena, and one increasingly sees discussion of the issue in the political press.

The experiences of the last twenty years or so probably make such issues even more relevant than ever. In the UK income inequality increased very rapidly since the late $1970 \mathrm{~s}^{3}$ Much of this has been due to changing rewards from paid work as earnings gaps between the highest and lowest paid workers widened out by a considerable amount. ${ }^{4}$ One consequence of this has been a massive rise in the proportion of children growing up in poverty. In 1979 13 percent of children lived in households where income was less than half of the average income. By 1996 this had risen to 33 percent (Gregg, Harkness and Machin, 1999). In 1999 the Prime Minister pledged to "end child poverty in a generation"5 Behind this lies the explicit belief that "childhood experience lays the foundations for later life. Children growing up in low-income households are more likely than others to have poor health, to do badly at school, become teenage mothers or come into early contact with the police, to be unemployed as adults or to earn lower wages $\%$

From a theoretical perspective there are a number of ways in which growing inequality and child poverty can influence intergenerational mobility. These are discussed in Grawe and Mulligan (2002). For example, the classic model of Becker and Tomes (1986) shows that the presence of credit constraints can lead to persistence of economic status across generations. If increased income inequality leads to a rise in the frequency or severity of credit constraints then this will lead to a fall in mobility. ${ }^{7}$ This may operate through stronger links between

\footnotetext{
1 See the survey undertaken in the recent Performance and Innovation Unit (2001) paper on social mobility.

2 See the up to date survey of Solon (1999).

3 See, inter alia, Goodman, Johnson and Webb (1997).

4 Machin (1996, 1998, 1999).

5 Tony Blair, Beveridge Lecture, $18^{\text {th }}$ March 1999.

${ }^{6}$ Page v, "Tackling Child Poverty: Giving Every Child the Best Possible Start in Life", HM Treasury, December 2001.

${ }^{7}$ See also Cameron and Heckman $(1998,2001)$.
} 
education and family income (as in Blanden, Gregg and Machin, 2002) that are generated by increased credit market imperfections. They may also be reinforced through increased labour market inequality generated by changing wage returns to education.

Previous empirical work (for example, Gregg and Machin, 1999) has identified the importance of educational attainment as a transmission mechanism between background and later outcomes. Another important development in the past twenty years or so is the very rapid educational upgrading that has taken place amongst the young. In 198013 percent of young people entered higher education. ${ }^{8}$ This rose sharply to 19 percent by 1990 and 31 percent by the year 2000. In addition the numbers of young people attaining no qualifications has fallen dramatically. We are keen to discover the implications of these changes for intergenerational mobility. The extent to which improved educational attainment is being spread equally or unequally amongst the population has clear implications for how intergenerational mobility may have altered through time. We consider this explicitly in our model and empirical work.

We look at these questions using data on two British birth cohorts (one born in 1958, the other in 1970). The paper begins, in the next section, by considering how existing work relates to our questions of interest and by describing the empirical methods we use. Section 3 describes the data. Section 4 presents our empirical results, where we report evidence showing that intergenerational immobility increases between the two cohorts we study. This occurs for both the regression and transition matrix approaches to studying intergenerational mobility. We also find that differing educational attainment accounts for part of the change in the association between parental income and children's earnings. We discuss the implications of these findings in the concluding section of the paper.

\section{Related Work and Modelling Questions}

\section{The intergenerational mobility literature}

Recent years have seen significant developments in the literature dealing with parent-child correlations of economic and social status, in large part because of the increasing availability

\footnotetext{
${ }^{8}$ These numbers are the higher education age participation index for young people, taken from the Department for Education and Skills Labour Market Information Database (Skillsbase). The exact definition used by DfES is the number of young (under 21) home initial entrants expressed as a percentage of the averaged 18 to 19 year old population. Initial entrants are those entering a course of full-time higher education for the first time.
} 
of good quality longitudinal data. Even so the majority of this growing literature has yet to address issues dealing with changes in the extent of intergenerational mobility in any detail.

The usual approach taken in this work is to estimate log linear regressions of children's economic status on that of their parents. ${ }^{9}$ The typical formulation for children and parents in family $\mathrm{i}$ is:

$$
\ln \mathrm{Y}_{\mathrm{i}}^{\mathrm{CHILD}}=\alpha+\beta \ln \mathrm{Y}_{\mathrm{i}}^{\mathrm{PARENTS}}+\varepsilon_{\mathrm{i}}
$$

where $\mathrm{Y}$ is economic status (usually labour market earnings) and $\varepsilon$ is an error term. The coefficient $\beta$ reflects how strongly children's status is associated with parental economic stature. The literature usually proceeds to say $\beta$ of zero (where child and parental $\mathrm{Y}$ are uncorrelated) corresponds to complete intergenerational mobility and $\beta$ of unity (child $\mathrm{Y}$ is fully determined by parental Y) corresponds to complete immobility. The empirical question of interest then concerns estimating the magnitude of $\beta$, paying careful attention to problems of measurement of Y and associated econometric difficulties.

The more recent work in this area very clearly points out the potential pitfalls associated with estimating $\beta$ from data on children and their parents. An older literature surveyed in Becker and Tomes (1986) concluded that, for correlations based on labour market earnings, $\beta$ was around 0.2. This led Becker and Tomes to say "aside from families victimized by discrimination, regression to the mean in earnings in the United States and other rich countries appears to be rapid" (Becker and Tomes, 1986, p.S32). However the methodological problems associated with the data used in the majority of this work meant that this estimate was biased downwards. Solon (1989) shows that the use of homogenous samples and measurement errors in $\mathrm{Y}_{\mathrm{i}}^{\text {PARENTS }}$ both induce an attenuation bias meaning that the $\beta$ coefficients from the earlier work tended to be too low. More recent work using better quality data and appropriate econometric methods concludes that the labour market earnings $\beta$ is in fact quite a lot higher, and more likely to be around 0.4 (Solon, 1999). ${ }^{10}$

\footnotetext{
${ }^{9}$ The other commonly adopted approach is to look at transition matrices between generations. All of what we discuss in this section could be framed in terms of the transition matrix approach and we do present estimates based on both the regression and transition matrix approaches later on. But for now, for reasons of clarity, we just focus on the regression approach. This of course goes back a long way in time (for example, see Galton's, 1886, analysis of child-parent height correlations).

${ }^{10}$ Some studies, like the recent one by Mazumder (2000), report even higher estimates (this is due to reducing attenuation bias as a result of time averaging parental earnings over a reasonably large number of years).
} 
These findings have potentially important implications for social welfare. Various authors have demonstrated a link between inequality and the extent of intergenerational mobility, with less mobility (higher $\beta$ ) implying greater inequality. Atkinson (1981), for example, writes down a simple model where this occurs. This link is important, especially if lack of mobility constrains higher ability children from lower income families. For example, if a higher $\beta$ results in such children having less access to resources whilst growing up or facing credit constraints that cuts short their education, for example by stopping them from attending university.

\section{Changes over time in the extent of intergenerational mobility}

The study of how $\beta$ may change through time becomes very important when placed in the context of this discussion. As already noted above, income inequality has risen in recent years, especially in the UK and US, and there have been big increases in the numbers of children gowing up in relatively poor families. Yet we know little of how this relates to possible changes in the intergenerational mobility of economic status. Part of this lack of knowledge is due to the strong data requirements that are likely to hinder researchers who would like to address this question. We only know of three studies that have attempted to consider this.

Fortin and Lefebvre (1998) use Canadian data from the General Social Surveys of 1986 and 1994. These surveys give the occupation, employment status, education and industry of fathers when the respondent was 15 and matching this with earnings data from the Canadian Census allows the authors to construct father's income. Comparing individuals in the same age groups across the two surveys fails to show any clear trend in Canadian intergenerational income mobility over time. Mayer and Lopoo's (2001) and Fertig (2001) use US data from the Panel Survey of Income Dynamics to consider how intergenerational transmissions have changed in the US. Both studies find an increase in intergenerational earnings mobility (i.e. a falling $\beta$ ) over time, despite there being a widening of inequality over the period considered. Mayer and Lopoo argue that this is a consequence of the increased investments made in children by the state that have counteracted the differences in the investments parents are able to make. However, in both studies the sample sizes used are small and some reported results are very much on the borders of statistical significance. 


\section{Mechanisms behind changes in intergenerational mobility}

What mechanisms are likely to underpin changes in the extent of intergenerational mobility? Mayer and Lopoo discuss three possibilities:

a) the relative investments in children made by rich and poor parents might change;

b) the payoff to these investments might change;

c) the returns to genetic or biologically transmitted characteristics change.

Solon (2001) has formalised the first two of these factors in an intuitively appealing economic model. Suppose we are interested in intergenerational earnings mobility. In generation $\mathrm{t}$ labour market earnings $\mathrm{W}$ are a function of human capital $\mathrm{H}$ so that:

$$
\mathrm{W}_{\mathrm{t}}=\phi_{\mathrm{t}} \mathrm{H}_{\mathrm{t}}+\mathrm{u}_{\mathrm{t}}
$$

where $u_{t}$ is a random error term.

If we then believe that children's human capital is related to parental income through differences in investments made by rich and poor parents we can write (with $\mathrm{v}_{\mathrm{t}}$ being an error term)

$$
\mathrm{H}_{\mathrm{t}}=\psi \mathrm{W}_{\mathrm{t}-1}+\mathrm{v}_{\mathrm{t}}
$$

One can combine these equations to generate an intergenerational mobility function:

$$
\mathrm{W}_{\mathrm{t}}=\phi_{\mathrm{t}} \psi \mathrm{W}_{\mathrm{t}-1}+\varepsilon_{\mathrm{t}}
$$

where $\varepsilon_{\mathrm{t}}=\phi_{\mathrm{t}} \mathrm{v}_{\mathrm{t}}+\mathrm{u}_{\mathrm{t}}$.

According to this formulation intergenerational mobility will be higher in this case if a) there are lower returns to human capital for children $\left(\phi_{t}\right.$ is lower), or $\left.b\right)$ if children's human capital is less sensitive to parental earnings ( $\psi$ is lower). On the former, there is plenty of evidence that educational wage differentials have been rising in the US and UK in recent years. ${ }^{11}$ This would imply reduced mobility. We know less about links between education

\footnotetext{
${ }^{11}$ The evidence on this is very clear in the US where wage gaps between the more and less educated have been rising since the late 1970s (see Card, 1999). The picture is less clear in the UK. Educational wage differentials rose sharply in the 1980s. Since then there has been less upward movement. However, the supply of educated workers has risen very sharply which one would normally think should depress educational wage differentials.
} 
and parental income though see Acemoglu and Pischke, 2001, who identify strong links between the two across US regions over time). But we do know that educational attainment has been rising very sharply. In the UK in 19755.6 percent of men had a degree. By 2000 this had risen to 17.9 percent. ${ }^{12}$ For women the rise is even faster, from 2.3 to 15.3 percent over the same time period. If this increased educational attainment differentially benefited more children from lower income families (lower $\psi$ ) then this would raise mobility. On the other hand, if children from richer families were more likely to reach higher educational qualifications (higher $\psi$ ) this will result in reduced mobility. For these reasons we also consider the role played by changing educational attainment in the empirical work we present below.

\section{Measurement of $\beta$ when inequality varies over time}

One of the motivating influences for our interest in changing intergenerational mobility is the fact that income inequality has been rising over time. This has important implications for the measurement of the intergenerational elasticity $\beta$. Grawe (2000b) demonstrates the implications of changing variances in parent and child earnings for the measurement of intergenerational mobility. His interest is in terms of the bias induced by measuring the parameter at different stages in the generations' lifecycles. Frequently in the literature the earnings measure for parents is taken later in life than the one for children. As the variance of earnings increases with age this can lead to biased estimates compared to when both measures are taken at the same point of the lifecycle. This leads to a downward bias in the estimated coefficient. Grawe shows that this can be corrected for by using the sample correlation between parental and child Y measures:

$$
\left(\operatorname{Corr}_{\ln Y^{\text {PARENTS }}, \ln Y^{\text {CHILD }}}\right)=\beta *\left(\frac{\mathrm{SD}_{\ln Y^{\text {PARENTS }}}}{\mathrm{SD}_{\ln \mathrm{Y}^{\mathrm{CHILD}}}}\right)
$$

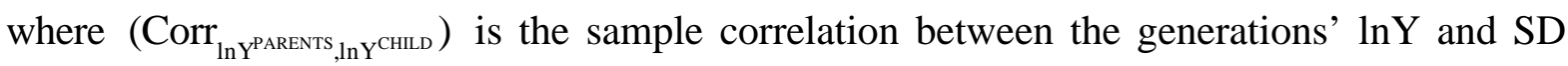
denotes a standard deviation.

\footnotetext{
This certainly has not happened: the 1990s pattern most likely displays a small rise, even in the face of increased supply (Machin, Harkness and McIntosh, 2001).

${ }^{12}$ See Machin, Harkness and McIntosh (2001).
} 
In the light of this discussion, it becomes clear that when comparing intergenerational mobility over a period when inequality is changing it is particularly important to correct for changes in the inequality of $\mathrm{Y}$. Therefore all our estimates report both the estimated regression coefficient $\beta$ and the sample correlation, which we term ' $\beta$ adjusted for changes in inequality'.

\section{The Data}

\section{The British birth cohorts}

We look at changing intergenerational mobility using data from two very rich British birth cohorts. These are the National Child Development Study (NCDS), a survey of all children born in the UK between 3 and 9 March 1958, and the British Cohort Survey (BCS), a survey of all children born between 5 and 11 April 1970. The NCDS is a very rich data set that has been used for previous work on intergenerational mobility in the UK (Dearden, Machin and Reed, 1997) and consists of the birth population with follow-up samples at ages 7, 11, 16, 23, 33 and $42 .{ }^{13}$ The BCS has been used less by economists, but is very similar in style, with data collected at ages 5,10,16, 26 and 30. As well as being similar in spirit the questions asked in the two cohorts are frequently identical, although there are some difficulties inherent in using them in a comparative study over time.

Ideally one would like to have measures of the same permanent economic status (be it wages or income) for both generations from both cohort studies. Unfortunately, due to different survey design, this is not possible. The NCDS parental income data comes from separate measures of father's earnings, mother's earnings and other income (all defined after taxes). Because of this breakdown earlier work on the NCDS was able to compare sons and father's earnings. However, the BCS only has data on parents' combined income. We are therefore forced to base our estimates on the relationship between the cohort member's earnings or income and parental income and are not able to look at changes in the pattern of intergenerational correlations of earnings.

As already mentioned, previous work in this area stresses the need to look at parents and children at the same stage of the lifecycle. This is because one does not want to

\footnotetext{
13 The NCDS data have also been used to look at the transmission mechanisms that may underpin intergenerational mobility: see Gregg and Machin (1999, 2000), Hobcraft (1998) or Kiernan (1995).
} 
contaminate estimates with measurement error due to the transitory components of earnings or income. We are able to get fairly close to this in our work, using income and earnings data on children at age 33 in the NCDS and 30 in the BCS. In case parents are of different ages across the studies we also control for the average age of parents. Controlling for average age rather than age of mother and father separately avoids limiting the sample to families with two parents. ${ }^{14}$

\section{Descriptive statistics}

Table 1 shows some descriptive statistics for our estimation samples. ${ }^{15}$ The first thing to notice is confirmation of the rising inequality of earnings between the cohorts, as shown by the higher standard deviations (in parentheses) for the 1970 cohort in the top row. There is also a rise in the inequality of cohort member's family incomes and in the inequality of parental incomes measured at age 16 (in 1974 for the NCDS and in 1986 for the BCS). The Table also shows the fraction of cohort members who were in poor families at age 16 (defined as below a poverty line of half mean equivalised national income ${ }^{16}$ ) to be higher for the 1970 cohort, which is in line with the national trends in child poverty reported in Gregg, Harkness and Machin (1999). Finally, substantial educational upgrading occurs. Many more BCS cohort members have a degree by their early 30s as compared to the older cohort.

\section{Estimates of Changes in Intergenerational Mobility}

\section{Baseline results}

Table 2 reports a set of baseline results, showing estimates of intergenerational mobility from both cohorts, for male and female cohort members separately. Three sets of results are reported for each. The first, in the upper panel of the Table, is a regression of the log of

\footnotetext{
14 The issue of whether the child is with their natural parents may be a cause of concern and is explicitly considered in Dearden, Machin and Reed (1997). We have re-run our estimates excluding children without both natural parents but find it does little to change our results. However our sample does exclude children with no traditional "parent" figure such as those living solely with grandparents or in an institutional setting.

15 Our estimation samples are restricted to those in employment at the time the age 30/33 data was collected. This is, of course, a necessary restriction in order for us to have wage data but is a non-trivial selection rule, particularly for women and is an issue that we hope to return to in future work.

16 This poverty line is from income data in the appropriate years from the Family Expenditure Survey, a representative household survey carried out annually in Britain.
} 
cohort members' earnings on log parental income. The second, which we refer to as the augmented earnings regression, adds a large set of pre-labour market entry controls to the first specification. These variables (listed in the notes to the Table) are a set of child-specific and family factors. The inclusion of these variables is an attempt to identify the effect of changes in family income for otherwise identical individuals. ${ }^{17}$ The final set of results uses cohort members' family income as the dependent variable.

Our main interest concerns changes in the extent of mobility over time. The results in Table 2 paint a strong and very consistent pattern. In all cases the BCS parental income coefficient is higher than the comparable NCDS coefficient. This remains the case when the inequality adjustment described earlier is implemented. Furthermore, the changes are sizeable with the inequality-adjusted estimates rising by .132 to .253 for men and by .113 to .230 for women. Similarly strong rises are seen in the augmented and family income regressions. All of these increases are strongly significant, showing a steep rise across cohorts that resulted in substantial falls in the extent of intergenerational mobility. This is the main empirical result of this paper. Links between child and parent economic status appear to have strengthened considerably in this cross-cohort comparison. We next go on to consider the robustness of this finding.

\section{Comparison with previous estimates}

Readers familiar with earlier work in this field may worry that the NCDS estimates of the intergenerational mobility coefficient for the NCDS are lower than the .4 'consensus estimate' mentioned earlier and also the estimates found for the same data in Dearden, Machin and Reed (1997). In this section we aim to allay these fears. We began by repeating the basic analysis of Dearden, Machin and Reed (1997) on our NCDS sample. We obtain an OLS coefficient (and associated standard error) from a regression of sons on father's earnings of $.259(.025)$ for 2122 observations. This compares with $.240(.027)$ for the more limited sample of 1565 observations in the original work.

Further analysis implies that it is the use of family income rather than fathers' earnings as the independent variable of interest that results in different magnitudes in the estimated

\footnotetext{
${ }^{17}$ One way of thinking about the inclusion of these characteristics is that they in some sense "level the playing field' between cohort members by controlling for detailed observables and as such proxy dhild/family fixed effects. Or at least that they show how the coefficients would alter if one moved more towards a fixed effects specification that would wash out child and family characteristics not previously controlled. The cohort studies are particularly suited to this estimation strategy as they contain much richer childhood data than other similar surveys (like the US National Longitudinal Survey of Youth).
} 
intergenerational elasticities. One plausible hypothesis that then emerges is that it may be differences in the influence of mother's earnings that underpin the rise in $\beta$ between the cohorts. If true this would imply that if we looked at family income where father's earnings were the only component then the estimates of $\beta$ would not change. To test this we repeated the baseline estimations for families in which only the father works. With these samples the gap in the adjusted $\beta$ falls for both sexes, from .132 in the full sample to .075 in the restricted sample for sons and from .113 to .092 for daughters. Therefore there is some (moderate) evidence that the changing influence of mothers may be driving some of the observed change. ${ }^{18}$ However, digging deeper into such gender differences is not the focus of this paper, as that would require substantial effort to be devoted to the development of a more general framework where parental inputs may differ for sons and daughters and where mother's work is incorporated explicitly. However, this is on the agenda for future research.

\section{Sensitivity checks and possible bias}

Great care has been taken in recent work in this area to try to ensure that results are not contaminated by measurement errors that can cause attenuation bias in estimates of intergenerational elasticities. This involves attempts to get rid of measurement errors in the variables entered on the right hand side of intergenerational mobility regressions. Two main approaches are followed. First, one can try and time average multiple observations on parental income to eliminate transitory components of income thereby getting closer to a measure of permanent economic status. Second, one can use instrumental variables techniques to get rid of measurement error.

We have some difficulties with implementing both of these approaches. Time averaging is not possible because the NCDS data has only one parental income measure. Similarly we do not believe that we have any credible instruments for parental income. ${ }^{19}$ Because of this we choose to follow a different route. Initially we take a look at the likely extent of measurement error in the BCS by time averaging over the age 10 and 16 income observations. Then we move to the cross-cohort comparison and discuss theoretically what

\footnotetext{
18 One should note that, due to increased labour force participation by women, the sample size is reduced by much more by placing this restriction on the BCS data than on the NCDS data.

19 This is despite the use of parental education and social class as instruments in Dearden, Machin and Reed (1997). Some limited experimentation here revealed that their use, especially in the cross cohort context, seemed rather dubious, both on the basis of Sargan tests and on the sensitivity of IV estimates to choice of instruments.
} 
potential biases could get rid of our falling mobility result. We discuss how plausible or implausible these might be, considering our own estimates of measurement error and those found in the literature.

Table 3 reports a set of $\beta$ estimates based on the age 10 and age 16 income data contained in the BCS data. The reported estimates are the age 16 estimates from Table 2, plus estimates based on age 10 data and then upon the time averaged age 10 and 16 income data. The first thing to notice is that the estimates based on age 10 and 16 data are identical for sons. There is a little more variation for daughters, but even here it is clear that the evidence of a cross-cohort rise in the regression $\beta$ remains in place. Furthermore, when one looks at the time averaged estimates of $\beta$ they show the pattern one expects: the estimated $\beta$ rises for both sons and daughters, revealing some evidence of attenuation bias from measurement errors, and the estimates rise by around .06 for sons and somewhere between .06 and .11 for daughters.

Moving on to the cross-cohort implications of measurement error, the starting point is clearly the observation that one would require more attenuation bias in the NCDS sample as compared to the BCS sample to start to question our findings. It is not obvious from the outset why there should be any reason to think this to be the case, but there are several relevant points to be made. In the past economists have worried that the timing of the UK "Three-Day Week" might have led to measurement error in the NCDS age 16 family income data. This question has been considered in Dearden, Machin and Reed (1997) and in Grawe (2000a). By comparing income measures taken during and after the policy Grawe finds that 5 percent of the whole NCDS sample is likely to have reported three-day income variables rather than standard ones, meaning that overall the attenuation bias from this possible source of measurement error is unlikely to be large.

Table 4 shows a calibration exercise on how much bigger the measurement error would be required to be in the NCDS for us to conclude there is no statistically significant rise in the adjusted $\beta$ across the cohorts, for various assumptions on measurement error in the BCS. For example, the first row of the Table shows that if we assume complete accuracy in the BCS one would require measurement error in the NCDS to be 36 percent for sons and 31 percent for daughters (that is, a change in the regression coefficient from .098 to .154 for sons and .169 to .245 for daughters), so that around one third of the variance in measured income would need to come from error. As we relax the assumptions on the accuracy of the BCS data it is clear that the measurement error required in the NCDS to get rid of the rise also 
increases and is often substantial. For example, if measurement error in the BCS is as high as Mazumder's (2000) recent paper suggests, the NCDS measurement error would need to be 70 percent for sons (61 percent for daughters) for the rise we observe to be rendered statistically insignificant. The Table shows under various assumptions that one would need substantially higher measurement error in the NCDS data to eliminate the pattern of rising intergenerational mobility across the two cohorts.

As mentioned above transitory income is usually thought of as the main source of measurement error in parental earnings or income mentioned in the literature. In order to get a handle on the effect this may have on our cohort estimates we have also investigated changes in the permanent versus transitory component of labour income in a large British data source, the New Earnings Survey panel. The New Earnings Survey is a 1 percent employer reported database covering all British employees carried out in April of each year. It contains very accurate wages data from employer records and enables one to follow people through time. One can use such data to work out the permanent and transitory components of earnings and compare them with the NCDS and BCS data. ${ }^{20}$

If the relative importance of the transitory component of income has decreased through time then this provides some independent evidence from another data source for the possibility of higher attenuation bias in the NCDS. It seems that the data is partly in line with this. Estimating a fixed effect earnings equation over 5 years of data for a cohort equivalent to the BCS fathers shows that transitory fluctuations in income account for 21 percent of the total variance. A comparable figure for NCDS fathers is slightly higher at 32 percent. However the last row of Table 4 shows the variance contribution of transitory income would need to be much higher than this (around 50 percent) to result in no statistically significant fall in mobility. In summary then, Table 4 shows that measurement error in the NCDS would need to be very substantial indeed to even reduce our observed rise to statistically insignificant levels, let alone to account for it entirely.

All this gives us confidence that we are picking up a genuine rise in the child-parent correlations across the NCDS and BCS cohorts. We next therefore consider how much of the

\footnotetext{
20 Dickens (2000) undertakes a detailed study of how much of the rise in earnings inequality seen in Britain is due to a rise in the permanent versus the transitory components of earnings. He finds about half of the rise in the variance of hourly earnings between 1975 and 1995 to be permanent.
} 
observed increase can be explained by the substantial educational upgrading we see across the cohorts.

\section{The role of education}

We noted in the earlier sections of the paper that changes in intergenerational correlations could come about if the correlations between earnings, education and parental income alter through time. To explore this we add variables measuring the education levels of cohort members to the intergenerational mobility regressions. The results are reported in Table 5 . They show education to have an important impact on the magnitude of the estimated $\beta$ for both cohorts, with a bigger (moderating) impact on the size of the BCS mobility parameter. As such the increased educational attainment of children and parents of the BCS cohort vis-àvis the NCDS cohort can explain part of the fall in intergenerational mobility.

The magnitude of this differs for sons and daughters. For sons the increase in the inequality adjusted $\beta$ is .132 unconditional on education. This falls to .110 once we control for son's education. For daughters the fall is bigger, going from an unconditional rise of .113 to a rise of .081 conditional on daughter's education. Therefore measured education accounts for 17 percent of the fall in mobility for sons and 28 percent for daughters. According to the simple economic model outlined earlier this result is in line with the fact that, particularly for females, the expansion in educational achievement between the cohorts has been concentrated on those from higher income backgrounds. This inequality in increased education supply has been acknowledged by the British Department for Education and Employment (DfEE) ${ }^{21}$ who say, "The increase in participation in the 1990s amongst socioeconomic groups $\mathrm{A}$ to $\mathrm{C}$ has been double that among groups $\mathrm{D}$ and $\mathrm{E}$ ". ${ }^{22}$ Figures from the DfEE show an increase in the participation rate of those from socio-economic groups D-E of five percentage points (from 11 to 16 percent) and an increase of ten percentage points for those from groups A-C (from 26 to 36 percent) ${ }^{23}$. This question is the focus of the (related) paper by Blanden, Gregg and Machin (2002) who report evidence that the education-parental

\footnotetext{
21 The Department for Education and Employment has become the Department for Education and Skills since the 2001 General Election.

${ }^{22}$ From David Blunkett's forward to 'Higher Education for the $21^{\text {st }}$ Century: Change in Higher Education' (1998) London, HMSO.

${ }^{23}$ Although the relationship between educational achievement and social class and the relationship between educational attainment and parental income are clearly not measuring quite the same issue the correlation between income and social class means we would expect them to be related.
} 
income relationship strengthened significantly across the two cohorts studied here, thereby confirming that education expansion heavily favoured children from higher income backgrounds.

\section{Transition matrices}

All of our analysis so far has concentrated on regression estimates of the extent of intergenerational mobility and how it has changed through time. The beauty of this approach lies in its simplicity and ease of interpretation but, of course, because of its focus on the single number average $\beta$ it is unclear about the way in which the nature of the mobility process is altering. One can explore this in more detail by looking at transition matrices, which show where child-parent pairs are moving across the distribution of economic status. Tables $6 \mathrm{a}$ and $6 \mathrm{~b}$ report a set of transition matrices for NCDS and BCS sons and daughters.

The Tables show the proportion in each parental income quartile that move into each quartile of the sons' or daughters' earnings distribution. The extent of immobility can be summarised by an immobility index that computes the sum of the leading diagonal and its adjacent cells. These are reported at the top of the Tables. These numbers can be interpreted relative to the immobility index in the case of perfect mobility. If all individuals had an equal chance of experiencing an adult income in each quartile all cells would contain .25 and the sum of the diagonal band would be 2.5. As we might expect, given what we learned from the regression analysis, all the immobility indexes we observe in the Table are above this number.

It is clear that transition analysis confirms the regression finding that mobility has fallen between the cohorts. In almost every case a higher proportion remain in the same quartile as their parents in the later cohort and there are less extreme movements between generations. In the NCDS 17 percent of sons and 18 percent of daughters with parents in the bottom quartile rise to the top; in the BCS this falls to 14 percent for sons and 15 percent for daughters. Moving in the other direction the growth in immobility is more marked with almost one fifth (19 percent for sons and 18 percent for daughters) of those who start life in the top quartile falling to the bottom in the NCDS while in the BCS the corresponding percentages are 14 for sons and 13 for daughters. The overall pattern of reduced mobility is very much confirmed by the pattern of results in the transition matrices. 
We further investigate the role of education as an explanatory factor in accounting for the fall in mobility in the transition matrices presented in Tables $7 \mathrm{a}$ and $7 \mathrm{~b}$ that control for education. For both sons and daughters an important portion of the observed fall in mobility is accounted for by the education variables. For sons, the immobility index rises by .14 conditional on education compared with .20 in the unconditional matrices in Table 6a. For daughters the conditional rise is .06 compared with .22 unconditionally. Thus the nonlinearities allowed for in the transition matrix approach do seem to imply a bigger education effect for both sons and daughters as compared to the average regression approach considered earlier (the immobility index is reduced by 30 percent for sons and by 73 percent for daughters). As such the increased educational attainment of the younger birth cohort seems to matter in interpreting the fall in intergenerational mobility observed across cohorts.

\section{Conclusions}

In this paper we have considered how the extent of intergenerational mobility has altered across two British birth cohorts, the first born in March 1958 and the second born in April 1970. Even though these cohorts are only twelve years different in age we see sharp falls in cross-generation mobility of economic status between the cohorts. The economic status of the 1970 cohort is much more strongly connected to parental economic status than the 1958 cohort. Our estimates enable us to calculate the difference in the earnings of young people born into the top and bottom quintiles of the family income distribution in the two different years. In the NCDS families in the top income quintile had an average income 3.47 times that of families from the bottom quintile. Our estimate of intergenerational mobility therefore suggests that the sons of the richest parents earned 113 percent more than the poorest sons. ${ }^{24}$ The same calculation for the BCS, where the parental income distribution is wider, shows that sons from the richest quintile earned 138 percent more than sons from the poorest family income quintile. $^{25}$

\footnotetext{
${ }^{24}$ Corak (2001) shows that by taking the antilog of $\ln Y_{i}^{\text {CHILD }}=\alpha+\beta \ln Y_{i}^{\text {PARENTS }}+\varepsilon_{i}$ then (ignoring $\varepsilon_{i}$ ) it is possible to show that the ratio of the earnings of children from high parental income backgrounds $(\mathrm{H})$ to those from low parental income backgrounds (L) is just the ratio of their parents' income raised to the power $\beta$, namely $\mathrm{Y}_{\mathrm{H}, \mathrm{t}} / \mathrm{Y}_{\mathrm{L}, \mathrm{t}}=\left(\mathrm{Y}_{\mathrm{H}, \mathrm{t}-1} / \mathrm{Y}_{\mathrm{L}, \mathrm{t}-1}\right)^{\beta}$.

${ }^{25}$ In the BCS the top quintile of parents had an average income 4.36 times that of the bottom quintile.
} 
We have found evidence that this fall in mobility can partly be accounted for by the fact that a greater share of the rapid educational upgrading of the British population has been focussed on people with richer parents. This unequal increase in educational attainment is thus one factor that has acted to reinforce more strongly the link between earnings and income of children and their parents. This seems to be an unintended consequence of the expansion of the university system that occurred in the late 1980s and early 1990s and an issue that needs to be borne in mind when considering future educational reforms. 
Table 1: Descriptive Statistics

\begin{tabular}{|l|c|c|c|c|}
\hline & $\begin{array}{c}\text { NCDS } \\
\text { Males }\end{array}$ & $\begin{array}{c}\text { BCS } \\
\text { Males }\end{array}$ & $\begin{array}{c}\text { NCDS } \\
\text { Females }\end{array}$ & $\begin{array}{c}\text { BCS } \\
\text { Females }\end{array}$ \\
\hline $\begin{array}{l}\text { Weekly wage } \\
\text { (NCDS Age 33; } \\
\text { BCS Age 30) }\end{array}$ & $\begin{array}{c}312.30 \\
(168.04)\end{array}$ & $\begin{array}{c}331.80 \\
(231.15)\end{array}$ & $\begin{array}{c}161.35 \\
(112.85)\end{array}$ & $\begin{array}{c}222.49 \\
(170.68)\end{array}$ \\
\hline $\begin{array}{l}\text { Family income } \\
\text { (NCDS Age 33; } \\
\text { BCS Age 30) }\end{array}$ & $\begin{array}{c}384.29 \\
(201.38)\end{array}$ & $\begin{array}{c}436.98 \\
(323.35)\end{array}$ & $\begin{array}{c}383.29 \\
(248.70)\end{array}$ & $\begin{array}{c}429.76 \\
(300.56)\end{array}$ \\
\hline $\begin{array}{l}\text { Parental income } \\
\text { (Age 16) }\end{array}$ & 306.40 & 320.58 & 305.48 & 319.94 \\
$(124.41)$ & $(167.22)$ & $(134.19)$ & $(165.25)$ \\
\hline $\begin{array}{l}\text { Proportion below poverty } \\
\text { line } \\
\text { (Age 16) }\end{array}$ & .06 & .11 & .07 & .10 \\
\hline $\begin{array}{l}\text { Proportion with degree } \\
\text { (NCDS Age 33; }\end{array}$ & .17 & .26 & .12 & .26 \\
BCS Age 30) & & & & \\
\hline Sample size & 2503 & 2053 & 2148 & 2018 \\
\hline
\end{tabular}

Notes:

1. Standard deviations in parentheses for wage and income measures.

2. Wage and income in January 2001 prices.

3. The sample sizes are as in the Table for all variables except for family income where they are: NCDS males 2348; BCS males 2015, NCDS Females 2438; BCS Females 2285. 
Table 2: Estimates of the Changes in the Extent of Intergenerational Mobility

\begin{tabular}{|c|c|c|c|c|c|c|}
\hline \multicolumn{7}{|c|}{ Earnings Regressions } \\
\hline & \multicolumn{2}{|c|}{ Regression $\beta$} & \multicolumn{2}{|c|}{$\begin{array}{c}\beta \text { Adjusted For } \\
\text { Changes in Inequality }\end{array}$} & \multirow[t]{2}{*}{$\begin{array}{c}\text { Change in } \\
\text { Adjusted } \beta\end{array}$} & \multirow[t]{2}{*}{ Sample Size } \\
\hline & NCDS & BCS & NCDS & BCS & & \\
\hline Sons & $\begin{array}{l}.098 \\
(.017)\end{array}$ & $\begin{array}{l}.219 \\
(.021)\end{array}$ & $\begin{array}{l}.120 \\
(.020)\end{array}$ & $\begin{array}{l}.253 \\
(.024)\end{array}$ & $\begin{array}{l}.132 \\
(.032)\end{array}$ & $\begin{array}{l}\text { NCDS: } 2503 \\
\text { BCS: } 2053\end{array}$ \\
\hline Daughters & $\begin{array}{l}.169 \\
(.030)\end{array}$ & $\begin{array}{c}.291 \\
(.028)\end{array}$ & $\begin{array}{l}.117 \\
(.021)\end{array}$ & $\begin{array}{l}.230 \\
(.022)\end{array}$ & $\begin{array}{l}.113 \\
(.030)\end{array}$ & $\begin{array}{c}\text { NCDS: } 2148 \\
\text { BCS: } 2017\end{array}$ \\
\hline \multicolumn{7}{|c|}{ Augmented Earnings Regressions } \\
\hline & \multicolumn{2}{|c|}{ Regression $\beta$} & \multicolumn{2}{|c|}{$\begin{array}{c}\beta \text { Adjusted For } \\
\text { Changes in Inequality }\end{array}$} & $\begin{array}{l}\text { Change in } \\
\text { Adjusted } \beta\end{array}$ & Sample Size \\
\hline & NCDS & BCS & NCDS & BCS & & \\
\hline Sons & $\begin{array}{l}.047 \\
(.017)\end{array}$ & $\begin{array}{l}.162 \\
(.024)\end{array}$ & $\begin{array}{l}.058 \\
(.020)\end{array}$ & $\begin{array}{l}.187 \\
(.027)\end{array}$ & $\begin{array}{l}.129 \\
(.034)\end{array}$ & $\begin{array}{c}\text { NCDS: } 2503 \\
\text { BCS: } 2053\end{array}$ \\
\hline Daughters & $\begin{array}{l}.058 \\
(.031) \\
\end{array}$ & $\begin{array}{c}.202 \\
(.033) \\
\end{array}$ & $\begin{array}{c}.041 \\
(.022) \\
\end{array}$ & $\begin{array}{l}.160 \\
(.026)\end{array}$ & $\begin{array}{l}.119 \\
(.034)\end{array}$ & $\begin{array}{c}\text { NCDS: } 2148 \\
\text { BCS: } 2017\end{array}$ \\
\hline \multicolumn{7}{|c|}{ Family Income Regressions } \\
\hline & \multicolumn{2}{|c|}{ Regression $\beta$} & \multicolumn{2}{|c|}{$\begin{array}{c}\beta \text { Adjusted For } \\
\text { Changes in Inequality }\end{array}$} & $\begin{array}{r}\text { Change in } \\
\text { Adjusted } \beta \\
\end{array}$ & Sample Size \\
\hline & NCDS & $\mathrm{BCS}$ & NCDS & $\mathrm{BCS}$ & & \\
\hline Sons & $\begin{array}{l}.089 \\
(.021)\end{array}$ & $\begin{array}{l}.267 \\
(.024)\end{array}$ & $\begin{array}{l}.089 \\
(.021)\end{array}$ & $\begin{array}{l}.256 \\
(.023)\end{array}$ & $\begin{array}{l}.167 \\
(.031)\end{array}$ & $\begin{array}{l}\text { NCDS: } 2348 \\
\text { BCS: } 2015\end{array}$ \\
\hline Daughters & $\begin{array}{l}.120 \\
(.025)\end{array}$ & $\begin{array}{l}.281 \\
(.026)\end{array}$ & $\begin{array}{l}.095 \\
(.020)\end{array}$ & $\begin{array}{l}.225 \\
(.021)\end{array}$ & $\begin{array}{l}.130 \\
(.029)\end{array}$ & $\begin{array}{c}\text { NCDS: } 2428 \\
\text { BCS: } 2285\end{array}$ \\
\hline
\end{tabular}

Notes:

1. Standard errors in parentheses.

2. All regressions control for parents' age and age-squared.

3. Augmented regressions include controls for ethnicity, parental education, family structure, whether father was unemployed during childhood and maths and reading test score quintiles at age $10 / 11$.

4. In the family income regressions the dependent variable is the sum of cohort member's earnings plus those of any partner. 
Table 3: Time Averaging Parental Income in the BCS

\begin{tabular}{|lcc|}
\hline Sons & Regression $\beta$ & BCS Sample size \\
\hline Income at age 16 & .210 & 1588 \\
Income at age 10 & $(.024)$ & \\
& .210 & 1588 \\
Time averaged (age 10 and age 16) income & $(.027)$ & 1588 \\
\hline Daughters & .273 & 1536 \\
Income at age 16 & $(.030)$ & BCS Sample size \\
Income at age 10 & .321 & 1536 \\
& $(.035)$ & \\
Time averaged (age 10 and age 16) income & .269 & \\
& $(.038)$ & \\
\end{tabular}

Notes:

1. Standard errors in parentheses. 
Table 4: Assumptions About the Extent of Possible Measurement Error Across Cohorts

\begin{tabular}{|c|c|c|c|c|c|}
\hline $\begin{array}{l}\text { Assumptions } \\
\text { on BCS Error }\end{array}$ & $\begin{array}{l}\text { BCS } \\
\text { Regression } \beta\end{array}$ & $\begin{array}{l}\text { BCS } \beta \\
\text { Adjusted For } \\
\text { Changes in } \\
\text { Inequality }\end{array}$ & $\begin{array}{l}\text { Implied adjusted } \\
\beta \text { for NCDS if } \\
\text { there were } \\
\text { no statistically } \\
\text { significant } \\
\text { change across } \\
\text { cohorts. }\end{array}$ & $\begin{array}{l}\text { Implied } \\
\text { NCDS } \\
\text { Regression } \beta\end{array}$ & $\begin{array}{l}\text { Implied } \\
\text { NCDS } \\
\text { Error }\end{array}$ \\
\hline \multicolumn{6}{|l|}{ Sons } \\
\hline 0 & .219 & .253 & .189 & .154 & $36 \%$ \\
\hline $10 \%$ & .241 & .278 & .214 & .175 & $44 \%$ \\
\hline Solon & & & & & \\
\hline $\begin{array}{l}14.52 \% \\
\text { Mazumder }\end{array}$ & .251 & .290 & .226 & .201 & $51 \%$ \\
\hline $\begin{array}{l}58 \% \\
\text { New Earnings } \\
\text { Survey }\end{array}$ & .400 & .462 & .398 & .325 & $70 \%$ \\
\hline $21 \%$ & .265 & .305 & .241 & .197 & $50 \%$ \\
\hline \multicolumn{6}{|l|}{ Daughters } \\
\hline 0 & .291 & .230 & .170 & .245 & $31 \%$ \\
\hline $\begin{array}{l}10 \% \\
\text { Solon }\end{array}$ & .320 & .253 & .193 & .278 & $39 \%$ \\
\hline $\begin{array}{l}14.52 \% \\
\text { Mazumder }\end{array}$ & .333 & .263 & .203 & .292 & $42 \%$ \\
\hline $\begin{array}{l}58 \% \\
\text { New Earnings } \\
\text { Survey }\end{array}$ & .460 & .363 & .303 & .437 & $61 \%$ \\
\hline $21 \%$ & .352 & .278 & .218 & .314 & $46 \%$ \\
\hline
\end{tabular}

Notes:

1. For sons no significant rise would require a difference in the adjusted coefficients of .064 or less. For daughters it would require a difference of .062.

2. Empirical estimates of the permanent component of earnings in the New Earnings Survey panel indicate that in our worst case the transitory component of labour income can have only risen to 32 percent in the NCDS, well within the bounds in the Table (see text of main body of paper). 
Table 5: Changes in Intergenerational Mobility and Educational Upgrading

\begin{tabular}{|lcccccc|}
\hline & \multicolumn{2}{c}{ Regression $\beta$} & \multicolumn{2}{c|}{$\beta$ Adjusted For } & Gap in & Sample Size \\
& \multicolumn{7}{c}{ Changes in Inequality } & Adjusted $\beta$ & \\
\hline & NCDS & BCS & NCDS & BCS & \\
\hline Sons & & & & & & \\
\hline Table 2 upper & .098 & .219 & .120 & .253 & .132 & NCDS: 2503 \\
panel & $(.017)$ & $(.021)$ & $(.020)$ & $(.024)$ & $(.032)$ & BCS: 2053 \\
Plus son's & .049 & .148 & .061 & .171 & .110 & NCDS: 2503 \\
education & $(.015)$ & $(.021)$ & $(.019)$ & $(.024)$ & $(.031)$ & BCS: 2053 \\
\hline Daughters & & & & & & \\
\hline Table 2 upper & .169 & .294 & .117 & .230 & .113 & NCDS: 2148 \\
panel & $(.030)$ & $(.028)$ & $(.021)$ & $(.023)$ & $(.031)$ & BCS: 1916 \\
Plus daughter's & .061 & .156 & .042 & .123 & .081 & NCDS: 2148 \\
education & $(.027)$ & $(.027)$ & $(.019)$ & $(.021)$ & $(.028)$ & BCS: 2018 \\
\hline
\end{tabular}

Notes:

1. Standard errors in parentheses.

2. All regressions control for parents' age and age-squared.

3. Educational attainment is modelled via educational qualification dummies (less than $\mathrm{O}$ level; $\mathrm{O}$ level or equivalent; greater than $\mathrm{O}$ level but less than degree; degree or higher). 
Table 6a: Quartile Transition Matrices For Sons

Immobility Index: NCDS 2.75 BCS 2.95

\begin{tabular}{|c|c|c|c|c|}
\hline NCDS & \multicolumn{4}{|c|}{ Sons' earnings quartile } \\
\hline $\begin{array}{l}\text { Parental income } \\
\text { quartile }\end{array}$ & Bottom & $2^{\text {nd }}$ & $3^{\text {rd }}$ & Top \\
\hline Bottom & .30 & .29 & .24 & .17 \\
\hline $2^{\text {nd }}$ & .28 & .25 & .26 & .20 \\
\hline $3^{\text {rd }}$ & .23 & .24 & .25 & .29 \\
\hline Top & .19 & .22 & .25 & .34 \\
\hline $\mathrm{BCS}$ & \multicolumn{4}{|c|}{ Sons' earnings quartile } \\
\hline $\begin{array}{l}\text { Parental income } \\
\text { quartile }\end{array}$ & Bottom & $2^{\text {nd }}$ & $3^{\text {rd }}$ & Top \\
\hline Bottom & .39 & .28 & .19 & .14 \\
\hline $2^{\text {nd }}$ & .25 & .29 & .29 & .16 \\
\hline $3^{\text {rd }}$ & .22 & .23 & .27 & .28 \\
\hline Top & .14 & .20 & .25 & .42 \\
\hline
\end{tabular}

Table 6b: Quartile Transition Matrices For Daughters

Immobility Index: NCDS 2.65 BCS 2.87

\begin{tabular}{|c|c|c|c|c|}
\hline NCDS & \multicolumn{4}{|c|}{ Daughters' earnings quartile } \\
\hline $\begin{array}{l}\text { Parental income } \\
\text { quartile }\end{array}$ & Bottom & $2^{\text {nd }}$ & $3^{\text {rd }}$ & Top \\
\hline Bottom & .26 & .28 & .27 & .18 \\
\hline $2^{\text {nd }}$ & .29 & .26 & .25 & .21 \\
\hline $3^{\text {rd }}$ & .27 & .22 & .26 & .26 \\
\hline Top & .18 & .24 & .22 & .35 \\
\hline $\mathrm{BCS}$ & \multicolumn{4}{|c|}{ Daughters' earnings quartile } \\
\hline $\begin{array}{l}\text { Parental income } \\
\text { quartile }\end{array}$ & Bottom & $2^{\text {nd }}$ & $3^{\text {rd }}$ & Top \\
\hline Bottom & .33 & .26 & .25 & .15 \\
\hline $2^{\text {nd }}$ & .31 & .29 & .22 & .18 \\
\hline $3^{\text {rd }}$ & .23 & .26 & .27 & .27 \\
\hline Top & .13 & .19 & .26 & .40 \\
\hline
\end{tabular}


Table 7a: Quartile Transition Matrices For Sons

Conditional on Sons' Education

Immobility Index: NCDS 2.64 BCS 2.78

\begin{tabular}{|c|c|c|c|c|}
\hline \multirow{2}{*}{$\begin{array}{c}\text { NCDS } \\
\begin{array}{c}\text { Parental income } \\
\text { quartile }\end{array}\end{array}$} & \multicolumn{4}{|c|}{ Sons' earnings quartile } \\
\hline & Bottom & $2^{\text {nd }}$ & $3^{\text {rd }}$ & Top \\
\hline Bottom & .28 & .28 & .24 & .20 \\
\hline $2^{\text {nd }}$ & .27 & .25 & .25 & .24 \\
\hline $3^{\text {rd }}$ & .24 & .24 & .26 & .25 \\
\hline Top & .21 & .23 & .25 & .31 \\
\hline $\mathrm{BCS}$ & \multicolumn{4}{|c|}{ Sons' earnings quartile } \\
\hline $\begin{array}{l}\text { Parental income } \\
\text { quartile }\end{array}$ & Bottom & $2^{\text {nd }}$ & $3^{\text {rd }}$ & Top \\
\hline Bottom & .33 & .28 & .22 & .17 \\
\hline $2^{\text {nd }}$ & .27 & .26 & .24 & .22 \\
\hline $3^{\text {rd }}$ & .22 & .25 & .28 & .26 \\
\hline Top & .19 & .21 & .26 & .35 \\
\hline
\end{tabular}

Table 7b: Quartile Transition Matrices For Daughters

Conditional on Daughters' Education

Immobility Index: NCDS 2.61 BCS 2.67

\begin{tabular}{ccccc}
\hline NCDS & \multicolumn{4}{c}{ Daughters' earnings quartile } \\
\hline $\begin{array}{c}\text { Parental income } \\
\text { quartile }\end{array}$ & Bottom & $2^{\text {nd }}$ & $3^{\text {rd }}$ & Top \\
\hline $\begin{array}{c}\text { Bottom } \\
2^{\text {nd }}\end{array}$ & .25 & .27 & .27 & .20 \\
$3^{\text {rd }}$ & .30 & .24 & .23 & .24 \\
Top & .23 & .26 & .25 & .26 \\
& .22 & .23 & .25 & .30 \\
\hline BCS & \multicolumn{5}{c}{} \\
\hline Parental income & Bottom & Daughters' earnings quartile & \\
quartile & & $2^{\text {nd }}$ & $3^{\text {rd }}$ & Top \\
\hline Bottom & .31 & .26 & .23 & .19 \\
$2^{\text {nd }}$ & .26 & .25 & .25 & .24 \\
$3^{\text {rd }}$ & .24 & .25 & .24 & .27 \\
Top & .19 & .24 & .28 & .30 \\
\hline
\end{tabular}




\section{References}

Acemoglu, D. and Pischke, S. (2001), 'Changes in the Wage Structure, Family Income, and Children's Education', European Economic Review, 45, pp. 890-904.

Atkinson, A. (1981), 'On Intergenerational Income Mobility in Britain', Journal of Post Keynesian Economics, 3, pp. 194-218.

Becker, G. and Tomes, N. (1986), 'Human Capital and the Rise and Fall of Families', Journal of Labor Economics, 107, pp. 123-150.

Blanden, J., Gregg, P. and Machin, S. (2002), 'Education and Family Income', mimeo.

Cameron, S. and Heckman, J. (1998), 'Life Cycle Schooling and Dynamic Selection Bias: Models and Evidence for Five Cohorts of American Males', Journal of Political Economy, 106, pp. 262-333.

Cameron, S. and Heckman, J. (2001), 'The Dynamics of Educational Attainment For Black, Hispanic and White Males', Journal of Political Economy, 109, pp. 455-499.

Card, D. (1999), 'The Causal Effect of Education on Earnings', in O. Ashenfelter and D. Card (eds.), Handbook of Labor Economics, Volume 3A, North Holland: Amsterdam.

Corak, M. (2001), 'Are the Kids All Right? Intergenerational Mobility and Child Well-Being in Canada', in The Review of Economic Performance and Social Progress, Center for the Study of Living Standards and Institute for Research on Public Policy, Canada.

Department for Education and Employment (1998), 'Higher Education for the $21^{\text {st }}$ Century: Change in Higher Education', HMSO: London.

Dearden, L., Machin, S. and Reed, H. (1997), 'Intergenerational Mobility in Britain', Economic Journal, 107, pp. 47-64.

Dickens, R. (2000), 'The Evolution of Individual Male Earnings in Great Britain: 1975-95', Economic Journal, 110, pp. 27-49.

Fertig, A. (2001), 'Trends in Intergenerational Earnings Mobility', Working Paper \#01-23, Center for Research on Child Well-Being, Princeton University.

Fortin, N. and Lefebvre, S. (1998), 'Intergenerational Income Mobility in Canada', in M. Corak (ed.), Labour Markets, Social Institutions and the Future of Canada's Children, Statistics Canada.

Galton, F. (1886), 'Regression Towards Mediocrity in Hereditary Stature', Journal of the Anthropological Institute of Great Britain and Ireland, 15, pp. 246-263.

Goodman, A., Johnson, P. and Webb, S. (1997), Inequality in the UK, Institute for Fiscal Studies. 
Grawe, N. (2000a), 'The Three-Day Week of 1974 and Measurement Error in the NCDS and FES Data Sets', mimeo.

Grawe, N. (2000b), 'Lifecycle Bias in the Estimation of Intergenerational Income Persistence', mimeo.

Grawe, N. and Mulligan, C. (2002), 'Economic Interpretations of Intergenerational Correlations', Working Paper 8948, National Bureau of Economic Research.

Gregg, P., Harkness, S. and Machin, S. (1999), 'Poor Kids: Child Poverty in Britain, 196696', Fiscal Studies, 20, pp. 163-187.

Gregg, P. and Machin, S. (1999), 'Childhood Disadvantage and Success or Failure in the Labour Market', in D. Blanchflower and R. Freeman (eds.), Youth Employment and Joblessness in Advanced Countries, National Bureau of Economic Research: Cambridge, MA.

Gregg, P. and Machin, S. (2000), 'The Relationship Between Childhood Experiences, Subsequent Educational Attainment and Adult Labour Market Performance', in K. Vleminckx and T. Smeeding (eds.), Child Well Being in Modern Nations: What do we Know?, Policy Press.

Hobcraft, J. (1998), 'Intergenerational and Life-Course Transmission of Social Exclusion: Influences and Childhood Poverty, Family Disruption and Contact With the Police', CASE Paper 15, Centre for Analysis of Social Exclusion, LSE.

Kiernan, K. (1995), 'Transition to Parenthood: Young mothers, Young Fathers - Associated Factors and Later Life Experiences', Discussion Paper Number WSP/113, Welfare State Programme, STICERD, LSE.

Machin, S. (1996), 'Wage Inequality in the UK', Oxford Review of Economic Policy, 7(1), pp. 47-64.

Machin, S. (1998), 'Recent Shifts in Wage Inequality and the Wage Returns to Education in Britain', National Institute Economic Review, 166, pp. 87-98.

Machin, S. (1999), 'Wage Inequality in the 1970s, 1980s and 1990s', in P. Gregg and J. Wadsworth (eds.), The State of Working Britain, Manchester University Press.

Machin, S., Harkness, S. and McIntosh, S. (2001), 'Changes in Educational Wage Differentials in Britain: Supply Changes and the Evolution of Wage Differentials by Sex and Subject of Study', mimeo.

Mayer, S. and Lopoo, L. (2001), 'Has the Intergenerational Transmission of Economic Status Changed?', mimeo.

Mazumder, B. (2000), 'Earnings Mobility in the US: a New Look at Intergenerational Mobility', mimeo. 
Performance and Innovation Unit (2001), 'Social Mobility: a Discussion Paper', available at http://www.cabinet-office.gov.uk/innovation/site/site.shtml.

Solon, G. (1989), 'Biases in the Estimation of Intergenerational Earnings Correlations', Review of Economics and Statistics, 71, pp. 172-174.

Solon, G. (1999), 'Intergenerational Mobility in the Labor Market', in O. Ashenfelter and D. Card (eds.), Handbook of Labor Economics, Volume 3A, North Holland: Amsterdam.

Solon, G. (2001), 'A Model of Intergenerational Mobility Variation over Time and Place', mimeo. 


\section{CENTRE FOR THE ECONOMICS OF EDUCATION Recent Discussion Papers}

25 S. Gibbons

24 D. Clark
R. Layard

S. McIntosh

A. Vignoles

22

D. Bonjour

L. Cherkas

J. Haskel

D. Hawkes

T. Spector

21
A. Chevalier
P. Dolton
S. McIntosh

20 G. Conlon

19 A. Jenkins

A. Vignoles

A. Wolf

F. Galindo-Rueda

$18 \quad$ S. Gibbons

$17 \quad$ S. Gibbons

16 R. Blundell

L. Dearden

B. Sianesi

15 S. Gibbons

S. Machin
Geography, Resources and Primary School Performance

Participation in Post-Compulsory Education in England:

What Explains the Boom and Bust?

Britain's Records on Skills

Returns to Education: Evidence from UK Twins
Recruiting and Retaining Teachers in the UK: an Analysis of Graduate Occupation Choice from the 1960s to the 1990s

The Determinants of Undertaking Academic and Vocational Qualifications in the UK

The Determinants and Effects of Lifelong Learning
Neighbourhood Effects on Educational Achievement

Paying for Good Neighbours? Neighbourhood Deprivation and the Community Benefits of Education

Estimating the Returns to Education: Models, Methods and Results

Valuing Primary Schools 

14 C. Megir
M. Palme
The Effect of a Social Experiment in Education
13 G. Conlon
One in Three? The Incidence and Outcomes of
LifelongLearners in the United Kingdom
12 A. Jenkins
Companies Use of Psychometric Testing and the Changing
Demand for Skills: A Review of the Literature
11 G. Conlon
The Differential in Earnings Premia Between Academically and Vocationally Trained Males in the United Kingdom
10 P. Dolton
O. D. Marcenaro
L. Navarro
9 P. Dolton
M. Silles
The Effective Use of Student Time: A Stochastic Frontier
Production Function Case Study
8 A. Chevalier
G. Lanot
Over-Education in the Graduate Labour Market: Some
Evidence
$7 \quad$ A. Chevalier
The Relative Effect of Family and Financial Characteristics on Educational Achievement
Graduate Over-Education in the UK
6 B. Sianesi
J. Van Reenen
The Returns to Education: A Review of the Macro-
Economic Literature
5 C. Harmon
H. Osterbeek
I. Walker
4 L. Dearden
S. McIntosh
M. Myck
A. Vignoles
The Returns to Education: A Review of Evidence,
Issues and Deficiencies in the Literature
The Returns to Academic and Vocational Qualifications in Britain
3 S. McIntosh
Measuring and Assessing the Impact of Basic Skills on
A. Vignoles
Labour Market Outcomes
$2 \quad$ A. Vignoles
R. Levacic
J. Walker
S. Machin
D. Reynolds
The Relationship Between Resource Allocation and Pupil Attainment: A Review

To order a discussion paper, please contact the

Publications Unit

Centre for Economic Performance

Tel 02079557673 Fax 02079557595 